\title{
Two new records of the genus Lecanora Ach. from Argentina
}

\section{Dos nuevos registros del género Lecanora Ach. para la Argentina}

\author{
Iris Nadia de la Rosa* \& María Inés Messuti \\ Instituto de Investigaciones en Biodiversidad y Medioambiente (INIBIOMA): Consejo Nacional de Investigaciones Científicas y \\ Técnicas-Universidad Nacional del Comahue (CONICET-UNComahue), Quintral 1250, R8400 FRF, San Carlos de Bariloche, \\ Río Negro, Argentina. \\ *irisnadia@gmail.com, nadia.delarosa@crub.uncoma.edu.ar
}

\section{RESUMEN}

Dos especies del género Lecanora, L. albella (Pers.) Ach. y L. hypocrocina Nyl., son registradas por primera vez para la Argentina. Se presentan comentarios, ilustraciones y mapa de distribución de las dos especies.

In connection with our ongoing revision of Lecanora Ach. (Lecanorales, lichenized Ascomycota) in Argentina, we found new and interesting records of this genus in the tropical and temperate regions of the country. Lecanora is a large lichen assemblage, heterogeneous and taxonomically complex, with a worldwide distribution that can be separated in several artificial species groups, namely subgeneric or infrageneric groups. The core of the genus, Lecanora sensu stricto, is characterized by crustose thalli, lecanorine apothecia, oxalate crystals in the apothecial margin, asci Lecanora-type, containing simple, colorless ascospores and atranorin and/or usnic acid in the cortex. Lecanora pallida and $L$. coronulans are two of the several subgeneric groups including in Lecanora sensu stricto. The former is defined by species with pruinose apothecia, without amphithecial cortex and frequently with protocetraric acid (Imshaug \& Brodo 1966). The species of $L$. coronulans group present a pigmented hypothecium in the apothecia and occurs exclusively in the tropics (Lumbsch et al. 1996). In this study, two species are recorder for the first time in Argentina, Lecanora albella (Pers.) Ach., a member of L. pallida group, and Lecanora hypocrocina Nyl., corresponding to the $L$. coronulans group. The species are commented, including illustrations and distribution map.

Specimens from BCRU, CTES and Ruhr MuseumEx Guderley herbaria were examined. The data from herbarium labels indicated in Material examined, including the type specimens, were copied literally. Observations and measurements were made on hand-cut sections and squash preparations, mounted in water, $10 \% \mathrm{KOH}$ (depicted as $\mathrm{K}$ ), Lugol's iodine (I) after pretreatment with $\mathrm{K}$ (indicated as $\mathrm{K} / \mathrm{I}$ ) and lactophenol cotton-blue (LCB). The crystals were observed with polarized light (pol+/-) and its solubility was tested with $\mathrm{K}$, on different sections of apothecia.
The chemical constituents were identified using high performance thin layer chromatography (HPTLC) and gradient-elution high performance liquid chromatography (HPLC) (Lumbsch 2002).

The species

Lecanora albella (Pers.) Ach., Lich. Univ. 369. 1810. Basionym: Lichen albellus Pers., Neue Ann. Bot. 5: 18 (1794). Type: Austria. Tyrol. "Prope runiam arcis Thaur" Schuler (= Krypt. Exs. Vind. 2170) (neotype SL-4002!). For the synonymy of this species see (Lumbsch et al. 1997). Fig. 1A, C

Lecanora albella is a member of the L. pallida group and is distinguished from other species of the genus by its white thallus, strongly pruinose disc, amphithecium without large oxalate crystals $(>10 \mu \mathrm{m})$, protocetraric acid and atranorin as major lichen substance. As occurs in other members of this complex, the marginal part of the amphithecium is not delimited by a true amphithecial cortex, but by a pseudocortex of amorphous hyphal mass, with small crystals (pol+, soluble in $\mathrm{K}$ ), interpreted as a medullary hyphae arranged in the same way as in the algal layer (Lumbsch et al. 1997).

This species is morphologically, anatomically and chemically very similar to $L$. caesiorubella Ach., other member of the L. pallida group. According to the literature (Lumbsch et al. 1997, Ryan et al. 2004), the size of the ascomata gives the most important differences to separate these two species. The apothecia of $L$. caesiorubella are usually larger $(0.3-3.0 \mathrm{~mm}$ diam. in $L$. caesiorubella vs. 0.3-1.5 mm diam. in L. albella) and have a more developed pseudocortex (45-150 $\mu \mathrm{m}$ thick in L. caesiorubella vs. 
20-75 $\mu \mathrm{m}$ thick in L. albella). However, it is observed that some specimens of $L$. caesiorubella may have small apothecia, while certain specimens of $L$. albella can have large ascomata. This overlapping, in addition to an indistinguishable chemistry, difficults the identification of the specimens, impeding significantly the separation of the taxa, sometimes only distinguishable by their different distribution. The delimitation of L. albella and L. caesiorubella remains doubtful (Lumbsch et al. 1997). The identified collections in this study as L. albella exhibit typical morphology and anatomy of the species (discussed above), with clearly small apothecia (0.4-1.0 mm diam.) and thin pseudocortex (20-50 $\mu \mathrm{m}$ thick). Unlike rimoseareolate thallus and white prothallus mentioned in previous descriptions for this species (Ryan et al. 2004), the material studied here usually has a rimose thallus and no prothallus has been observed.

Lecanora albella is widely distributed in the Northern Hemisphere (in northern regions of Africa, Asia, Europe and North America) on bark of conifers and deciduous trees (Imshaug \& Brodo 1966, Lumbsch et al. 1997, Ryan et al. 2004). In the Southern Hemisphere, L. albella was previously registered in New Zealand and Chile (Galloway 1985, Pereira 2007, Pereira \& San Martín 1998, Pereira et al. 2002, 2006, Zahlbruckner 1933). During this research, this species has been found in Argentina and in new localities of Chile. This is the first record of the species for Argentina (Río Negro and Chubut provinces).
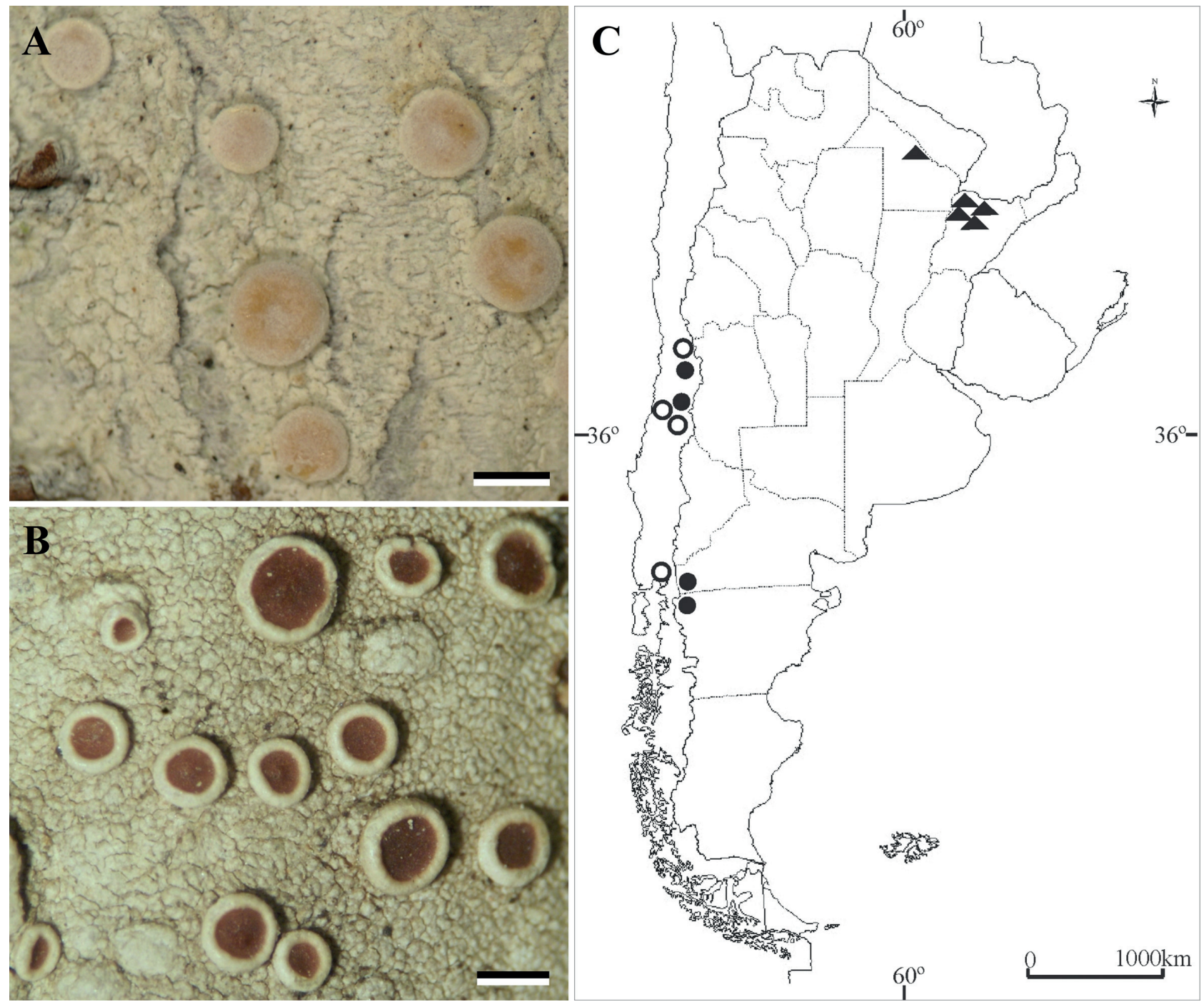

Figure 1. Habitus and distribution in Argentina and Chile of L. albella and L. hypocrocina. A, L. albella, habitus; B, L. hypocrocina, habitus; C, Distribution: L. hypocrocina $(\bullet)$ and L. albella [previous records $(\mathbf{0})$, new records $(\bullet)$ ]. Scale bar: A, B = $1 \mathrm{~mm}$.

Figura 1. Hábito y distribución en Argentina y Chile de L. albella y L. hypocrocina. A, L. albella, hábito; B, L. hypocrocina, hábito; C, Distribución de L. hypocrocina (• ) y L. albella [registros previos (o), registros nuevos (•)]. Escala: A, B=1 mm. 
In Argentina, L. albella was registered on bark of Acer pseudoplatanus L., Lomatia hirsuta (Lam.) Diels and Malus sp., generally inhabiting temperate open areas, in Nothofagus spp. forests of the Andean-Patagonian region (Cabrera 1994).

Material examined. ARGENTINA, Prov. de Río Negro, lago Steffen, zona cercana al lago, 6-III-1993, Messuti (BCRU 4836). Provincia de Chubut, Parque Nacional Lago Puelo, pinar alrededor de la intendencia del parque, 9-V2009, de la Rosa (BCRU 5251); ibid., cerca de la casa del guardaparque, 9-V-2009, de la Rosa (BCRU 5252); ibid., picada al Jardín Botánico, alrededores de la intendencia del parque, 9-V-2009, de la Rosa (BCRU 5249). CHILE, Región del Maule, Prov. Talca, El Colorado, ca. 48 km östl. Talca an der Route nach Argentinien, Sklerophyllwald am

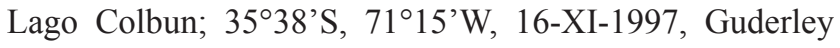
\& Pereira 157 (Herbarium Ruhr Museum-Ex Guderley) entrada a la Reserva Nacional Altos del Lircay, bosque

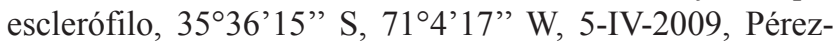
Ortega 1402 (BCRU 5368). AUSTRIA. Salzburg, Pinzgau, Valley of the Kapruner Ache, NE of Kitzsteinhorn, SW of Kesselfall hut, "Naturwaldreservat Kessellfall", mapleash-forest near a rivulet, $970 \mathrm{~m}$ alt., 15-XI-1993, Rücker \& Wittmann (BCRU 5035).

Lecanora hypocrocina Nyl., Flora 59: 509. 1876. Type: Cuba. "In ins., Wright, Lich Cubae be. II n 48 "[H-NYL 27297-lectotype!, UPS 117889 (L-68079)-isotype!]”.

Fig. 1B, C

Lecanora hypocrocina is easily recognized by its $\mathrm{K}+$ dark red to purple reaction in the hypothecium, due to the presence of skirin, boriquinone and other quinones. The presence of a reddish hypothecium places this species within the L. coronulans group, characterized by taxa with pigmented hypothecium. Other distinctive features are red-brown apothecial disc, epihymenium pulicaris-type, relatively small ascospores and the production of fatty acids (Lumbsch et al. 1996). Some specimens of L. hypocrocina with relatively dark apothecial disc may be confused with L. hypocrocinoides Lumbsch. However, the latter species shows a chlarotera-type epihymenium, longer ascospores (10.5-13.5 $\mu \mathrm{m}$ in L. hypocrocinoides vs. 7-12.5 $\mu \mathrm{m}$ in $L$. hypocrocina) and zeorinon as major secondary compound in addition to atranorin.

According to observations made by others authors (Lumbsch et al. 1996, Ryan et al. 2004), L. hypocrocina has an amphithecial cortex 10-15 $\mu \mathrm{m}$ wide and parathecium without crystals (pol-). Unlike these records, the material found in this study has a slightly wider amphithecial cortex $(15-25 \mu \mathrm{m})$, and parathecium with or without crystals (pol \pm ). This corticolous species is distributed in tropical region of east Africa, Central and South America. In South America, has been previously recorded for Brazil and Paraguay (Lumbsch et al. 1996). This is the first record of the species for Argentina (Chaco and Corrientes provinces).

The studied material was found on bark of Astronium balansae Engl., Caesalpinia paraguariensis (D. Parodi) Burkart and Schinopsis balansae Engl., in xerophilous and subtropical forests from northern Argentina.

Material examined. ARGENTINA. Prov. Chaco, Dpto. Gral. San Martín, zona Pampa del Indio, IX-1991, Barreto (CTES 342333). Prov. Corrientes, Dpto. San Cosme, río Paraná y arroyo San Juan, 10-X-1976, Schinini et al. 14182 (CTES 75621); ca. $15 \mathrm{~km}$ nordöstl. Corrientes, offenes Wald- und Weidegebiet (bosque de Quebracho colorado y Urunday);

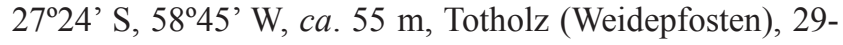
XI-1997, Guderley \& Ferraro (Herbarium Ruhr MuseumEx Guderley 213); ca. $15 \mathrm{~km}$ südöstl. Corrientes an der Route 5 Richtung San Luis del Palmar, Chaco (Quebracho), $27^{\circ} 29^{\prime}$ S, 5840' W, ca. 50 m, Rinde, 30-XI-1997, Guderley \& Ferraro (Herbarium Ruhr Museum-Ex Guderley 217); Dpto. Mburucuyá, Parque Nacional Mburucuyá, Potrero 18, 7-IV-2007, Michlig \& Niveiro (BCRU 5314).

\section{ACKNOWLEDGEMENTS}

We are grateful to Sergio Pérez-Ortega, Museo Nacional de Ciencias Naturales, Spain, and the curator of Ruhr Museum for sending us material for examination. UNComahue and CONICET (PIP N 11220090100207) provided financial support.

\section{REFERENCES}

CABrera, A.L. 1994. Regiones fitogeográficas argentinas. Enciclopedia argentina de agricultura y jardinería tomo II, fasc. 1, $2^{\text {nd }}$ ed. Acme, Buenos Aires, Argentina. 85 pp.

GallowaY, D.J. 1985. Flora of New Zealand. Lichens. P.D. Hasselberg, Government Printer, Wellington, New Zealand. $662 \mathrm{pp}$.

Imshaug, H.A. \& I.M. Brodo. 1966. Biosystematic studies on Lecanora pallida and some related lichens in the Americas. Nova Hedwigia 12(1-2): 1-59.

LumBsch, H.T. 2002. Analysis of phenolic products in lichens for identification and taxonomy. In: I. Kanner, R.P. Beckett \& A.K. Varma (eds.), Protocols in Lichenology Vol. 17, pp. 281-295. Springer-Verlag Berlin, Germany.

Lumbsch, H.T., R. Guderley \& J.A. Elix. 1996. A revision of some species in Lecanora sensu stricto with a dark hypothecium (Lecanorales, Ascomycotina). Bryologist 99(3): 269-291.

Lumbsch, H.T., M. Plümper, R. Guderley \& G.B. Feige. 1997. The corticolous species of Lecanora sensu stricto with pruinose apothecial discs. Acta Universitatis Upsaliensis, 
Symbolae Botanicae Upsalienses 32(1): 131-162.

Pereira, I. 2007. Micobiota liquenizada del Parque Katalapi, X Región, Chile. Gayana Botánica 64(2): 192-200.

Pereira, I. \& J. SAN MARtín. 1998. Flora liquénica corticícola en un bosque caducifolio de Nothofagus alessandri de Chile Central. Cryptogamie, Bryologie et Lichénologie 19(1): 59-72.

Pereira, I., J. SAn Martín \& M. Moya. 2002. Epiphytic lichens on Gomortega keule (Gomortegaceae) in the coastal mountains of Central Chile. Mitteilungen aus dem Institut für allgemeine Botanik in Hamburg 30-32: 171-185.
Pereira, I., F. Müller \& A. Valderrama. 2006. Diversity and distribution of bryophytes and lichens of El Colorado, Central Chile. Nova Hedwigia 83: 117-127.

Ryan, B.D., H.T. Lumbsch, M.I. Messuti, C. Printzen, L. Śliwa \& T.H. Nash. 2004. Lecanora. In: T.H. Nash, B.D. Ryan, G. Gires \& F. Bungartz, (eds.), Lichen flora of the greater Sonoran Desert Region Vol. 2, pp: 176-286. Arizona State University, Arizona, USA.

Zahlbruckner, A. 1933. Líquenes del herbario del Museo de Santiago de Chile. Revista Chilena de Historia Natural 37: 165-170.

Recibido: 26.09 .14

Aceptado: 06.06.15 